\title{
Microbial degradation of cellulosic material under intermediate-level waste simulated conditions
}

\author{
NaJi M. Bassil ${ }^{1,2}$, Alastair D. Bewsher ${ }^{1}$, Olivia R. Thompson ${ }^{3}$ and Jonathan R. Lloyd ${ }^{1, *}$ \\ 1 Research Centre for Radwaste Disposal \& Williamson Research Centre for Molecular Environmental Science, School \\ of Earth, Atmospheric and Environmental Sciences, The University of Manchester, Oxford Road, Manchester \\ M13 9PL, UK \\ 2 National Council for Scientific Research - Lebanon (CNRS-L), Beirut, Lebanon \\ 3 National Nuclear Laboratory, 5th Floor, Chadwick House, Warrington Road, Birchwood Park, Warrington WA3 6AE, \\ UK
}

[Received 10 October 2014; Accepted 3 March 2015; Associate Editor: Nicholas Evans]

\section{ABSTRACT}

Under the alkaline conditions expected in an intermediate-level waste repository, cellulosic material will undergo chemical hydrolysis. This will produce hydrolysis products, some of which can form soluble complexes with some radionuclides. Analyses of samples containing autoclaved tissue and cotton wool incubated in a saturated solution of $\mathrm{Ca}(\mathrm{OH})_{2}(\mathrm{pH}>12)$ confirmed previous reports that isosaccharinic acid (ISA) is produced from these cellulose polymers at high $\mathrm{pH}$. However, when inoculated with a sediment sample from a hyperalkaline site contaminated with lime-kiln waste, microbial activity was implicated in the enzymatic hydrolysis of cellulose and the subsequent production of acetate. This in turn led to acidification of the microcosms and a marked decrease in ISA production from the abiotic alkali hydrolysis of cellulose. DNA analyses of microbial communities present in the microcosms further support the hypothesis that bacterial activities can have a controlling influence on the formation of organic acids, including ISA, via an interplay between direct and indirect mechanisms. These and previous results imply that microorganisms could have a role in attenuating the mobility of some radionuclides in and around a geological disposal facility, via either the direct biodegradation of ISA or by catalysing cellulose fermentation and therefore preventing the formation of ISA.

\section{Introduction}

Cellulose is a polymer of $100-14,000$ glucose units linked by $\beta-1,4$ glycosidic bonds and is the main component of plant cell walls. As such, it is one of the most abundant polymers on Earth (Beguin and Aubert, 1994). Cellulose polymers are oriented in parallel and form highly ordered, insoluble crystalline domains interspersed by

* E-mail: jon.lloyd@manchester.ac.uk DOI: 10.1180/minmag.2015.079.6.18 more disordered amorphous regions. Cellulose can be present in a variety of products including clothes, paper, tissue etc., which are expected to be present in intermediate-level waste (ILW) that will be disposed of in a deep geological disposal facility (GDF) (Nuclear Decommissioning Authority, 2014).

Previous studies have shown that hyperalkaline conditions ( $\mathrm{pH}$ 12-13) will dominate after resaturation of an ILW-GDF with groundwater, due to the extensive use of cement (Berner, 1992). Under these hyperalkaline conditions, abiotic hydrolysis of the cellulose present in ILW will

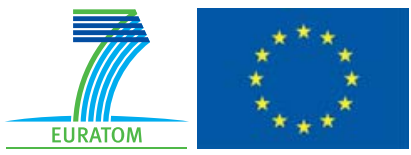

The publication of this research has been funded by the European Union's European Atomic Energy Community's (Euratom) Seventh Framework programme FP7 (2007-2013) under grant agreements $n^{\circ} 249396$, SecIGD, and n`323260, SecIGD2. 
take place, leading to the formation of watersoluble low molecular-weight compounds, in particular ISA (Glaus et al., 1999). ISA is a particular concern as it has the potential to bind to, and mobilize, some radionuclides (Gaona et al., 2008; Keith-Roach, 2008). Studies have shown that the rate and extent of cellulose hydrolysis under alkaline conditions is dependent on a number of factors, including the starting $\mathrm{pH}$, temperature and the degree of polymerization of the cellulose (Van Loon and Glaus, 1997; Van Loon et al., 1999; Pavasars et al., 2003; Glaus and Van Loon, 2008). In this respect, native cellulose (exemplified by cotton wool) has a greater degree of polymerization and a smaller fraction of reducing end groups than treated cellulose (e.g. tissue) and therefore the rate and extent of hydrolysis of cotton wool is less than that of tissue.

In addition to abiotic hydrolysis mechanisms, microorganisms can also break down cellulose enzymatically. These cellulolytic organisms are taxonomically diverse, belonging to different genera in the Bacterial and Eukarial domains, and are found in a wide range of environments under aerobic and anaerobic conditions (Leschine, 1995; Lynd et al., 2002). Furthermore, alkaliphilic and alkalitolerant cellulolytic bacteria from alkali lakes have been identified previously (Grant et al., 2004; Zhilina et al., 2005). They can play an important role in influencing their surrounding environment through the breakdown of cellulose and the fermentation of its component glucose monomers (Zhilina and Zavarzin, 1994).

Previous work by our group has shown that alkaliphilic bacteria present in a sediment from a legacy lime-working site, were able to utilize ISA as an electron donor for the reduction of a number of electron acceptors at $\mathrm{pH} 10$ (Bassil et al., 2014). The aim of this present work is to test the ability of the bacteria present in a similar sediment to survive the initial hyperalkaline $\mathrm{pH}$ that is expected in an ILW-GDF and then to (1) study their ability to degrade cellulosic material (tissue and cotton wool) at high $\mathrm{pH}$, and hence (2) control the biogeochemical fate of cellulose degradation products under anaerobic conditions.

\section{Materials and Methods}

\section{Sediment acquisition}

Sediment samples were collected from a depth of $\sim 20 \mathrm{~cm}$ from the surface of a site near Buxton, UK, which has been contaminated for decades by high pH lime-kiln workings (Rizoulis et al., 2012).

\section{Sample preparation}

Samples were prepared by adding $25 \%(\mathrm{w} / \mathrm{v})$ of tissue or cotton wool into $100 \mathrm{ml}$ serum bottles and adding to them a $100 \mathrm{ml}$ aliquot of saturated $\mathrm{Ca}(\mathrm{OH})_{2}$ solution $(1 \mathrm{~g} / \mathrm{l})$. The bottles were closed with rubber butyl stoppers, degased with $\mathrm{N}_{2}$ for $10 \mathrm{~min}$ and then autoclaved. After cooling, the bottles were introduced into an anaerobic chamber where a $2.5 \%(\mathrm{w} / \mathrm{v})$ inoculum of sediment was added to some of the bottles, while others were kept sterile (uninoculated). Triplicates were incubated for 30 months at 25 and $50^{\circ} \mathrm{C}$ for each condition. Sampling was undertaken initially every 2 months for the first 6 months of incubation and then every 6 months. During sampling, the bottles were opened inside the anaerobic chamber after its $\mathrm{O}_{2}$ level had dropped to zero, and $5 \mathrm{ml}$ volumes of the liquid along with small sections of the cellulosic material were removed and put in sterile $15 \mathrm{ml}$ tubes. A $1 \mathrm{ml}$ volume was taken from the $15 \mathrm{ml}$ tubes and was used for $\mathrm{pH}$ measurement and ionexchange chromatography analysis, while the remaining solution was frozen at $-20^{\circ} \mathrm{C}$.

\section{lon-exchange chromatography}

The $1 \mathrm{ml}$ samples were vortexed and then centrifuged at $13,000 \mathrm{~g}$ for $5 \mathrm{~min}$ at room temperature to remove bacteria and any solid material. The samples were diluted 50-200 times (with time, more ISA was produced and therefore the samples needed to be diluted further), then analysed by ionexchange high-performance liquid chromatography, following the protocol reported previously (Bassil et al., 2014). Preparation of the Ca salt of $\alpha$-ISA was performed following the procedure reported by Vercammen et al. (1999) and was used as a standard for ion-exchange high-performance liquid chromatography.

\section{Microbial community analyses}

\section{S and 18S rDNA gene amplification}

The frozen inoculated tissue samples from the start of the experiment $\left(\mathrm{T}_{0}\right)$ and after 30 months of incubation $\left(\mathrm{T}_{30}\right)$ at $25^{\circ} \mathrm{C}$ were thawed and DNA was extracted from them using the PowerSoil DNA isolation kit (MO BIO Laboratories, Carlsbad, California, USA), according to the manufacturer's 
protocol. The presence of bacterial, archaeal and fungal DNA in these samples was assessed using an end-point polymerase chain reaction (PCR) targeting the 16S rRNA and 18S rRNA genes, using the TaKaRa Ex Taq DNA Polymerase (TaKaRa Bio Inc, Japan). Bacterial DNAwas detected by using the $16 \mathrm{~S}$ rRNA gene universal primers 8F (5'-AGAGTTTG ATCCTGGCTCAG-3') and 1492R (5'-TACGG YTACCTTGTTACGACTT-3') (Lane, 1991), archaeal DNA was detected by using the archaeal specific 16S rRNA gene primers $21 \mathrm{~F}$ (5'-TTCCGG TTGATCCYGCCGGA-3') and 985R (5'-YCCGG CGTTGAMTCCAATT-3') (DeLong, 1992), and fungal DNA was detected by using 18S rRNA gene primers nu-SSU-0817-5' (5'-TTAGCATGG AATAATRRAATAGGA-3') and nu-SSU-1536-3' (5'-ATTGCAATGCYCTATCCCCA-3') (Borneman and Hartin, 2000). A negative control for the PCR reaction contained PCR-grade water and was run under the same conditions as the test samples. DNA extracted from Geobacter sulfurreducens, Methanoh alophilus halophilus and Handkea fumosa were used as positive controls for the PCR reaction for the detection of bacteria, archaea and fungi, respectively. The PCR products were run, along with a 2000 $100 \mathrm{bp}$ DNA ladder, for $45 \mathrm{~min}$ at $80 \mathrm{~V}$ on a $1 \%$ agarose gel in Tris-acetate-EDTA buffer, which was then observed on a Gel Doc XR system (Bio-Rad Laboratories, Hercules, California, USA).

\section{4 pyrosequencing}

Pyrosequencing PCR was performed on DNA extracted from samples 1 and 3 from the tissue microcosms that were incubated at $25^{\circ} \mathrm{C}$ at the initial $\left(\mathrm{T}_{0}\right)$ and final $\left(\mathrm{T}_{30}\right)$ time-points following the procedure reported by Bassil et al. (2014). The PCR product was sequenced at the University of Manchester sequencing facility using a Roche 454 Life Sciences GS Junior system (Roche, Basel, Switzerland). Analysis of the raw 454 pyrosequencing data was performed according to the protocols reported by Bassil et al. (2014).

\section{Results}

The abiotic alkali hydrolysis of cellulose was demonstrated through the increase in concentrations of ISA over time in autoclaved tissue and cotton wool samples incubated at 25 and $50^{\circ} \mathrm{C}$ in the presence of $\mathrm{Ca}(\mathrm{OH})_{2}$ at saturation for 30 months (Fig. 1). At $50^{\circ} \mathrm{C}$, these samples showed a decrease in $\mathrm{pH}$ (from $\mathrm{pH} 11.8$ to 9.4 and from 12.1 to 9.9 in the tissue and cotton wool samples, respectively) and an increase in ISA concentration (to 10.4 and $3.5 \mathrm{~mm}$ of ISA). At $25^{\circ} \mathrm{C}$ however, they showed an almost constant $\mathrm{pH}$ (ranging from 12 to 11.8 and from 12.3 to 12 ) and a smaller production of ISA (6.5 and $1.5 \mathrm{mM}$ ). The microcosms that were
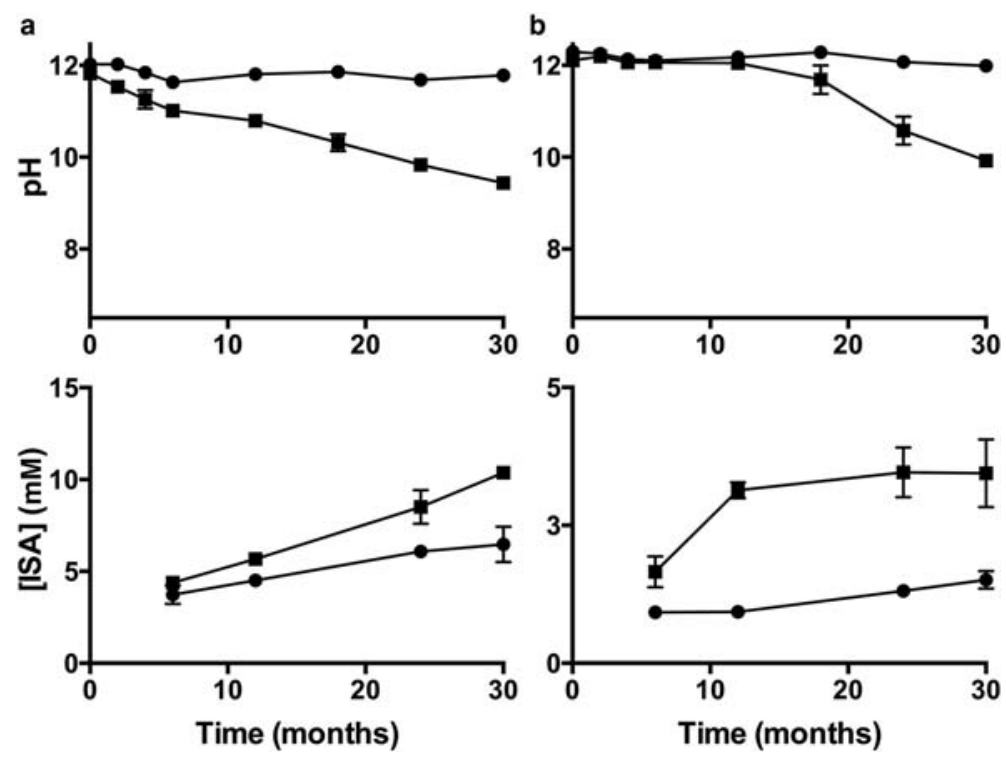

FIG. 1. Autoclaved tissue $(a)$ and cotton wool $(b)$ samples incubated at $25(-)$ and $50^{\circ} \mathrm{C}(\boldsymbol{\square})$ in the presence of $\mathrm{Ca}(\mathrm{OH})_{2}$ at saturation. The upper diagrams show the $\mathrm{pH}$ and the lower diagrams show the concentration of ISA in $\mathrm{mM}$. 
a
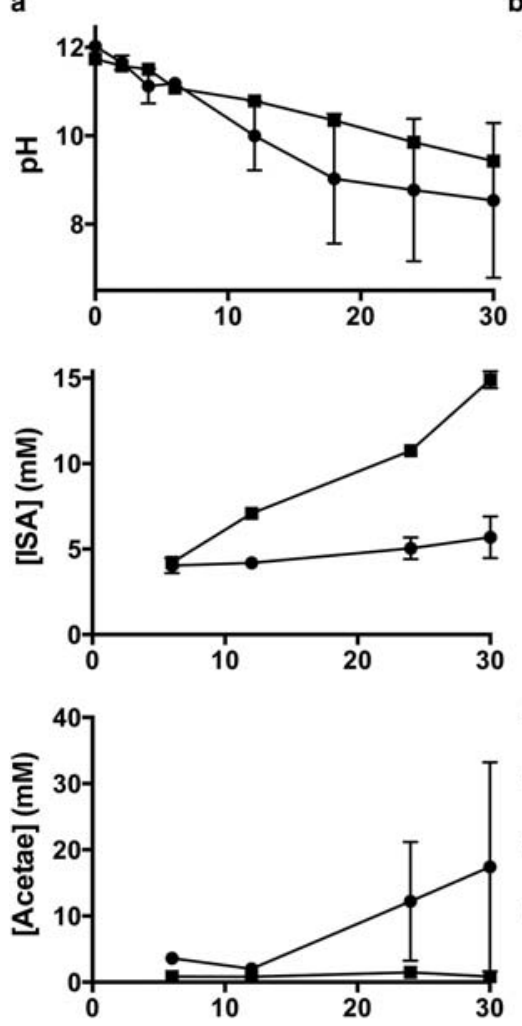

Time (months) b
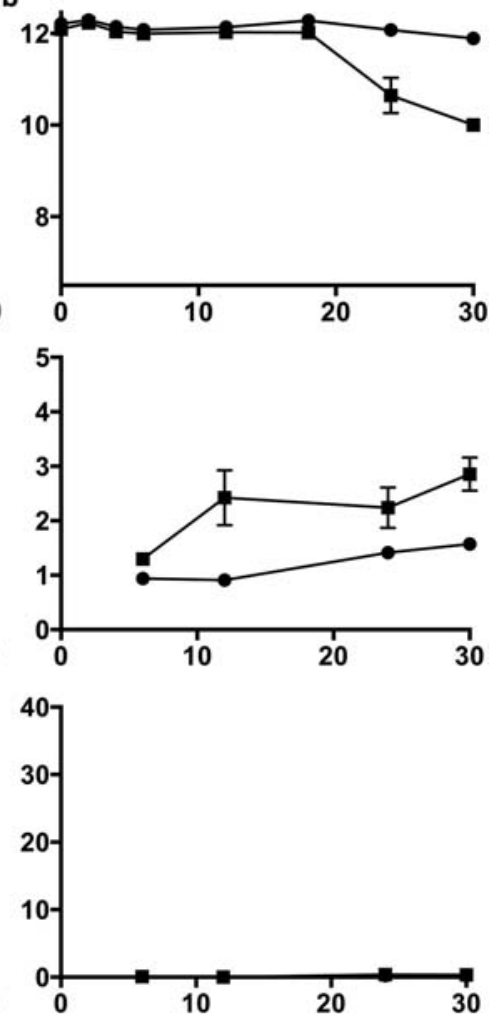

Time (months)

FIG. 2. Tissue (a) and cotton wool (b) microcosms (inoculated with $2.5 \%$ (w/v) of the lime-kiln sediment) incubated at 25 (O) and $50^{\circ} \mathrm{C}(\mathbf{-})$ in the presence of $\mathrm{Ca}(\mathrm{OH})_{2}$ at saturation. The upper diagrams show the $\mathrm{pH}$, the middle diagrams show the concentration of ISA in $\mathrm{mM}$ and the lower diagrams show the concentration of acetate in $\mathrm{mM}$.

inoculated with $2.5 \%(\mathrm{w} / \mathrm{v})$ of the lime-workings sediment showed a similar $\mathrm{pH}$ and ISA profile to the uninoculated samples under the same conditions at $50^{\circ} \mathrm{C}$ (Fig. 2). However, the tissue microcosms that were incubated at $25^{\circ} \mathrm{C}$ showed a prominent fall in $\mathrm{pH}$ (from $\mathrm{pH} 12$ to $\sim 8.5$ ) that was associated with an increase in acetate concentration to $17.4 \mathrm{mM}$ (Fig. 2). Furthermore, one of the samples of this triplicate (sample 1) showed visibly far more cellulose degradation (Fig. 3), a significant decrease in $\mathrm{pH}$ and far more acetate production than noted in the other two samples of the triplicate

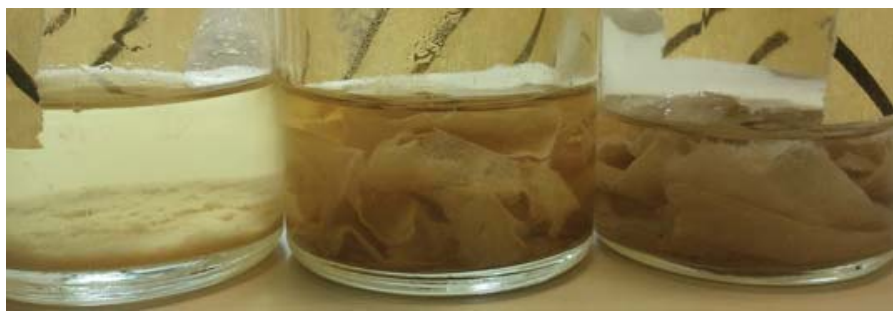

FIG. 3. The triplicate of the tissue microcosms, incubated for 30 months at $25^{\circ} \mathrm{C}$ and in the presence of $\mathrm{Ca}(\mathrm{OH})_{2}$ at saturation. Samples 1, 2 and 3 are shown from left to right. 

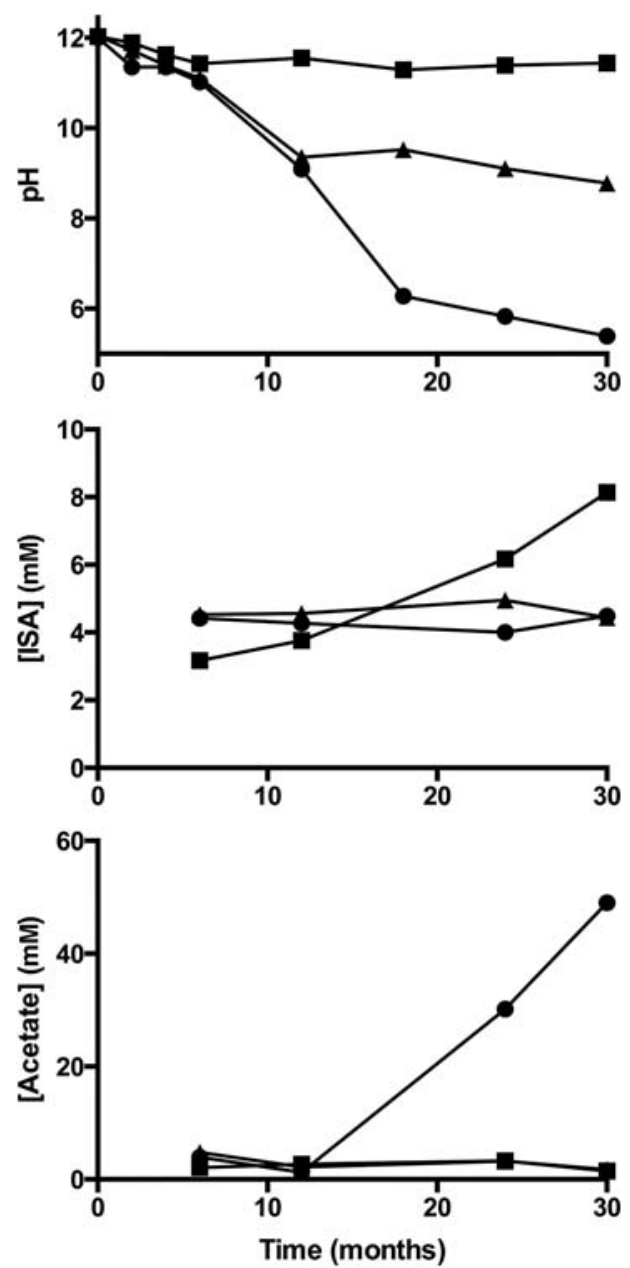

FIG. 4. The triplicate of the tissue microcosms incubated at $25^{\circ} \mathrm{C}$ and in the presence of $\mathrm{Ca}(\mathrm{OH})_{2}$ at saturation. The upper diagram shows the $\mathrm{pH}$, the middle diagram shows the concentration of ISA in $\mathrm{mM}$ and the lower diagram shows the concentration of acetate in mM. Sample 1(O), sample $2(\boldsymbol{\Delta})$ and sample $3(\boldsymbol{\bullet})$ are shown.

(Fig. 4), causing an increase in the error bars with time (Fig. 2). Comparison of the 16S rRNA gene sequences amplified at the beginning and the end of the $25^{\circ} \mathrm{C}$ incubation period for the inoculated tissue microcosms, showed an increase in the yield of amplified bacterial DNA in samples 1 and 3 over time, but not in sample 2 (which may contain very low biomass levels). Furthermore, it proved impossible to amplify archaeal or fungal rRNA genes by PCR in any of these microcosms (Fig. 5). Interestingly, samples 1 and 3 also showed an almost constant concentration of $\sim 4.5 \mathrm{mM}$ of ISA over the duration of the experiment, while sample 2 showed an increase in ISA concentration to $8.1 \mathrm{mM}$ after 30 months of incubation (Fig. 4).

Identification of the bacteria present in the tissue microcosms (samples 1 and 3) by 454 pyrosequencing, showed that the overall bacterial diversity dropped in sample 1 (from 160 to 27 OTUs) but not in sample 3 after 30 months of incubation at $25^{\circ} \mathrm{C}$ (Fig. 6a). Furthermore, there was an increase in the abundance of Firmicutes in both microcosms 1 and 3 , comprising $99.6 \%$ and $44.7 \%$ of the total $16 \mathrm{~S}$ rRNA gene sequenced after 30 months of incubation, respectively (Fig. 6b). Although microcosm 1 was dominated by bacteria belonging to the genera Clostridium and Sporomusa, sample 3 contained a consortium of mainly Firmicutes belonging to the genera: Bacillus, Clostridium and Pelosinus, along with non-Firmicutes such as Pseudomonas and Diaphorobacter (Fig. 6c).

\section{Discussion}

Bacteria have been found flourishing in natural environments that are considered to be extreme for life on Earth, for example soda lakes (Grant et al., 2004; Zhilina et al., 2005), deserts (An et al., 2013) and hydrothermal vents (Robidart et al., 2013). An ILW-GDF is expected to be an engineered extreme environment where different factors such as hyperalkaline conditions, high-radiation levels and high concentrations of radionuclides will be present, which could restrict microbial activity. Some host rocks and barrier materials may also limit water and available pore space for microbial colonization for operational periods of the GDF. However, the ILW-GDF will also contain electron donors $\left(\mathrm{H}_{2}\right.$ and organic material) and acceptors $\left(\mathrm{NO}_{3}^{-}, \mathrm{Fe}(\mathrm{III}), \mathrm{SO}_{4}^{2-}\right.$, etc.) that bacteria can utilize to support growth.

Sterile tissue and cotton wool samples incubated at 25 and $50^{\circ} \mathrm{C}$ for 30 months in a saturated solution of $\mathrm{Ca}(\mathrm{OH})_{2}$ confirmed previous results that a higher temperature and lower degree of polymerization (tissue has a lower degree of polymerization than cotton wool) generate more ISA from the abiotic alkali hydrolysis of cellulosic material (Fig. 1) (Van Loon and Glaus, 1997; Van Loon et al., 1999; Pavasars et al., 2003; Glaus and Van Loon, 2008). Although the starting $\mathrm{pH}$ of the samples used in the current study were less than those tested by previous groups, due to the use of $\mathrm{Ca}(\mathrm{OH})_{2}$ instead of $\mathrm{NaOH}$ and $\mathrm{KOH}$, our results are 


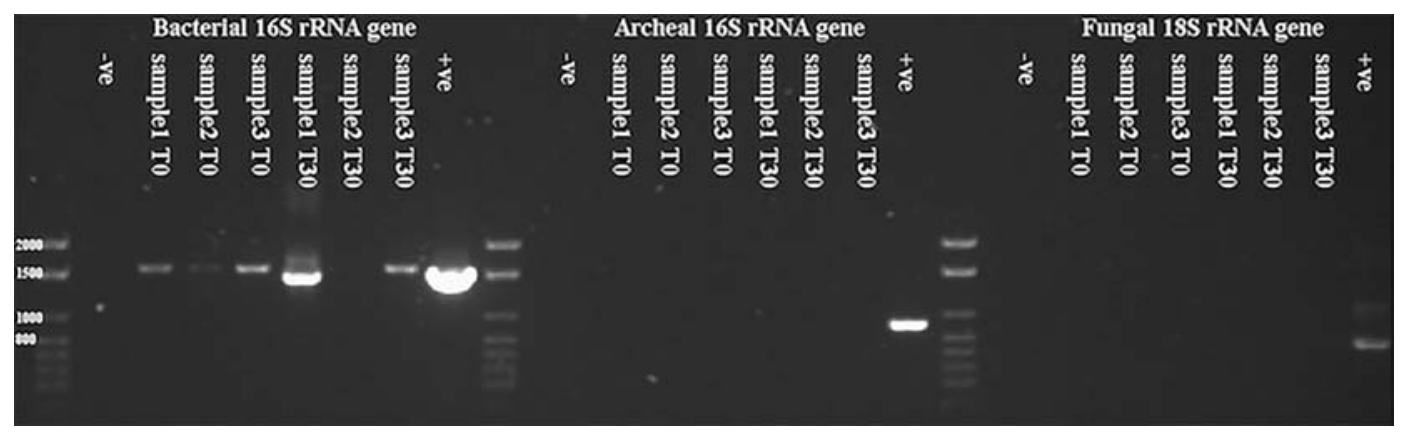

FIG. 5. Agarose gel electrophoresis of PCR products amplified using primers for the bacterial 16S rRNA gene, the archaeal 16S rRNA gene and the fungal 18S rRNA gene. In each set, from left to right, the lanes represent, the 2000100 bp DNA ladder, the negative control (containing molecular biology grade water) for the PCR reaction, samples 1,2 and 3 at $\mathrm{T}_{0}$, samples 1,2 and 3 at $\mathrm{T}_{30}$ and, finally, a positive control for the PCR reaction (containing DNA extracted from Geobacter sulfurreducens, Methanohalophilus halophilus and Handkea fumosa as representatives of bacteria, archaea and fungi, respectively).

representative of the more prolonged second phase of the evolution of a GDF, when $\mathrm{Ca}^{2+}$ will dominate the solution chemistry (Berner, 1992).

The fall in $\mathrm{pH}$ of the inoculated tissue microcosms that were incubated at $25^{\circ} \mathrm{C}$, the production of acetate (Fig. 2) and the visible degradation of cellulose (Fig. 3), are strong indicators of the biological degradation and fermentation of cellulose. This contrasts with the results from experiments conducted at $50^{\circ} \mathrm{C}$, where microbial activities were not implicated, presumably because inocula from the lime-workings site could not adapt to grow at elevated temperatures. Note, however, that moderate thermophiles capable of growth at such temperatures are common in hotter environments (An et al., 2013). It should also be noted that microbial activity was only implicated in 2 of the 3 inoculated $25^{\circ} \mathrm{C}$ triplicates (Fig. 4), possibly due to the heterogeneous distribution of active biomass in the initial sediment used for the inoculation of the microcosms (Fig. 6c). It may also be due to the development of lower $\mathrm{pH}$ niches in some of the microcosms (the samples were only shaken every 6 months during sampling), where some bacteria could have thrived by fermenting the added cellulosic material, which would have, in turn, caused a drop in the $\mathrm{pH}$ of the whole microcosm. Despite these differences between the triplicate samples the microcosms that showed the greatest yields of bacterial DNA (Fig. 5) also showed a cessation of ISA production (Fig. 4), which may be due to the decrease in $\mathrm{pH}$ associated with microbial activity, which in turn limited the abiotic production of ISA.
The increase in bacterial DNA yield (Fig. 5) and the drop in bacterial diversity (Fig. $6 a$ ) in the tissue microcosm (sample 1) after 30 months of incubation at $25^{\circ} \mathrm{C}$, indicates the selection of specific bacteria that are able to proliferate under ILW-GDF simulated conditions. In contrast to previous data reported on the bacterial diversity in surface lowlevel waste disposal sites (Field et al., 2010), which were dominated by Gram-negative Proteobacteria, the tissue microcosm in this study that supported bacterial growth (sample 1), was dominated by Gram-positive Firmicutes. Members of this latter group produce recalcitrant endospores that may give them the advantage needed to survive under hyperalkaline $\mathrm{pH}$ conditions. The dominance of Clostridia in this sample was expected as a number of species belonging to the Clostridium genus are anaerobic, spore-forming, cellulolytic bacteria (Leschine, 1995). Methane production could have a significant impact on C-14 transport and is a concern for an ILW-GDF safety case, so it is interesting to note the presence of the Sporomusa genus (some species of which are homoacetogenic) (Fig. 6c), along with the absence of methanogenic archaea (Fig. 5). These results suggest that methanogenesis is minimal in our high-pH model system, but clearly warrants further research under alkaline conditions, which have been poorly studied in this context. Collectively, these results indicate that environmental microorganisms may be able to survive, as recalcitrant spores, the initial hyperalkaline $\mathrm{pH}$ that is expected to dominate on closure of the repository and subsequent resaturation with groundwater. It is important to note that 

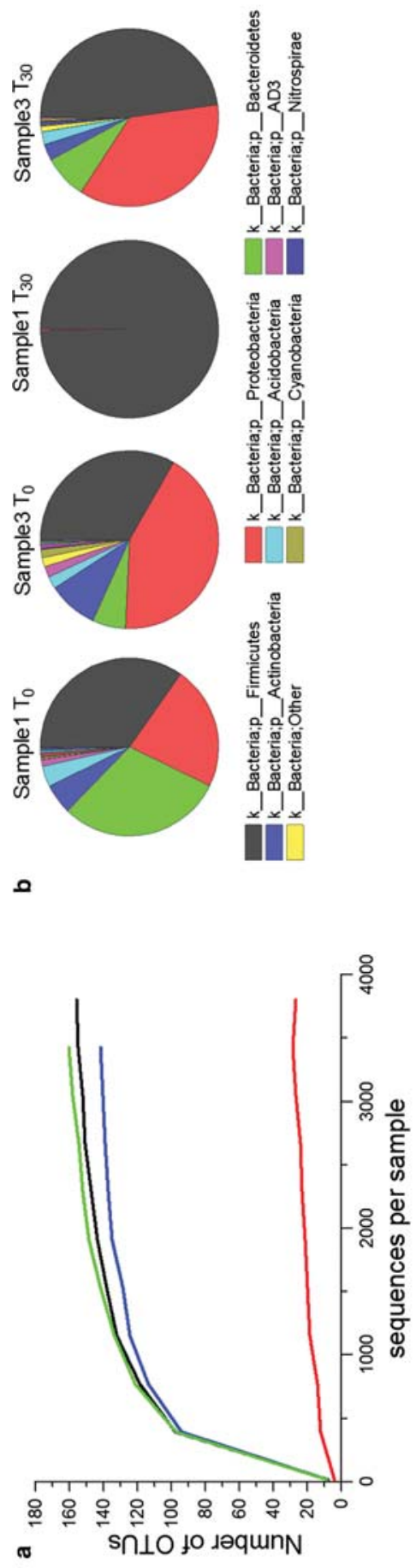

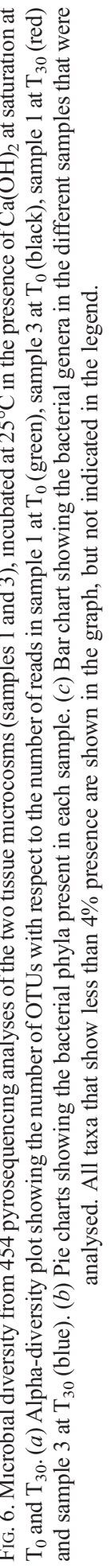


the $\mathrm{pH}$ in the GDF will stay hyperalkaline for a much longer period than in our microcosm experiments, however bacterial spores are known to survive for extended periods (thousands of years) in a range of environments (O'Sullivan et al., 2014). Furthermore, when the conditions become more suitable for growth, alkaliphilic, anaerobic bacteria may be able to affect the chemistry in and around the GDF through the degradation and fermentation of the cellulose present, and the subsequent production of $\mathrm{CO}_{2}, \mathrm{H}_{2}$, acetate and other fermentation products. Although it will depend largely on the amount of cement added and the amount of cellulose present, these fermentation products could have an impact on the $\mathrm{pH}$ buffering in zones affected by GDF processes (especially in niche areas), promoting colonization by a wider range of non-alkaliphilic microorganisms including neutrophiles.

In conclusion, these and previous results (Bassil et al., 2014), suggest that microorganisms are capable of colonizing high-pH environments analogous to those that will develop in an ILWGDF. These microorganisms have the potential to play a controlling role in moderating the production (via fermentation processes observed in this study) and/or the subsequent degradation of radionuclide complexants, such as ISA (e.g. by coupling its oxidation to the reduction of electron acceptors such as nitrate (Bassil et al., 2014)). Such activities should be considered when predicting the longterm biogeochemical evolution of ILW-GDFs.

\section{Acknowledgements}

This work was supported by the BIGRAD consortium under the UK Natural Environmental Research Council (NE/H007768/1) and The National Nuclear Laboratories Signature Research Programme. The authors thank Christopher Boothman for help with setting up the microcosms. JRL acknowledges support from the Royal Society. NMB thanks the National Council for Scientific Research-Lebanon.

\section{References}

An, S., Couteau, C., Luo, F., Neveu, J. and DuBow, M.S. (2013) Bacterial diversity of surface sand samples from the Gobi and Taklamaken deserts. Microbial Ecology, 66, 850-860.

Bassil, N.M., Bryan, N. and Lloyd, J.R. (2014) Microbial degradation of isosaccharinic acid at high $\mathrm{pH}$. The ISME Journal, 9, 310-320.
Beguin, P. and Aubert, J.P. (1994) The biological degradation of cellulose. FEMS Microbiology Reviews, 13, 25-58.

Berner, U.R. (1992) Evolution of pore water chemistry during degradation of cement in a radioactive waste repository environment. Waste Management, 12, 201-219.

Borneman, J. and Hartin, R.J. (2000) PCR primers that amplify fungal rRNA genes from environmental samples. Applied and Environmental Microbiology, 66, 4356-4360.

DeLong, E.F. (1992) Archaea in coastal marine environments. Proceedings of the National Academy of Sciences, 89, 5685-5689.

Field, E.K., D’Imperio, S., Miller, A.R., VanEngelen, M. R., Gerlach, R., Lee, B.D., Apel, W.A. and Peyton, B.M. (2010) Application of molecular techniques to elucidate the influence of cellulosic waste on the bacterial community structure at a simulated low-level-radioactive-waste site. Applied and Environmental Microbiology, 76, 3106-3115.

Gaona, X., Montoya, V., Colas, E., Grive, M. and Duro, L. (2008) Review of the complexation of tetravalent actinides by ISA and gluconate under alkaline to hyperalkaline conditions. Journal of Contaminant Hydrology, 102, 217-227.

Glaus, M.A. and Van Loon, L.R. (2008) Degradation of cellulose under alkaline conditions: New insights from a 12 years degradation study. Environmental Science \& Technology, 42, 2906-2911.

Glaus, M.A., Van Loon, L.R., Achatz, S., Chodura, A. and Fischer, K. (1999) Degradation of cellulosic materials under the alkaline conditions of a cementitious repository for low and intermediate level radioactive waste part i: Identification of degradation products. Analytica Chimica Acta, 398, 111-122.

Grant, S., Sorokin, D.Y., Grant, W.D., Jones, B.E. and Heaphy, S. (2004) A phylogenetic analysis of Wadi el Natrun soda lake cellulase enrichment cultures and identification of cellulase genes from these cultures. Extremophiles, 8, 421-429.

Keith-Roach, M.J. (2008) The speciation, stability, solubility and biodegradation of organic co-contaminant radionuclide complexes: A review. Science of the Total Environment, 396, 1-11.

Lane, D.J. (1991) 16S/23S rRNA sequencing. Pp. 115-174 in: Nucleic Acid Techniques in Bacterial Systematics (E. Stackebrandt and M. Goodfellow, editors). John Wiley \& Sons Ltd., London.

Leschine, S.B. (1995) Cellulose degradation in anaerobic environments. Annual Review of Microbiology, 49, 399-426.

Lynd, L.R., Weimer, P.J., Van Zyl, W.H. and Pretorius, I.S. (2002) Microbial cellulose utilization: Fundamentals and biotechnology. Microbiology and Molecular Biology Reviews, 66, 739-739.

Nuclear Decommissioning Authority (2014) The 2013 UK Radioactive Waste Inventory: Radioactive Waste 


\section{MICROBIAL DEGRADATION OF CELLULOSE}

Composition. Nuclear Decommissioning Authority, Moor Raw, Cumbria, UK.

O’Sullivan, L.A., Roussel, E.G., Weightman, A.J., Webster, G., Hubert, C.R.J., Bell, E., Head, I., Sass, H. and Parkes, R.J. (2014) Survival of Desulfotomaculum spores from estuarine sediments after serial autoclaving and high-temperature exposure. The ISME Journal, 9, 922-933.

Pavasars, I., Hagberg, J., Boren, H. and Allard, B. (2003) Alkaline degradation of cellulose: Mechanisms and kinetics. Journal of Polymers and the Environment, 11, 39-47.

Rizoulis, A., Steele, H.M., Morris, K. and Lloyd, J.R. (2012). The potential impact of anaerobic microbial metabolism during the geological disposal of intermediate-level waste. Mineralogical Magazine, 76, 3261-3270.

Robidart, J., Callister, S.J., Song, P., Nicora, C.D., Wheat, C.G. and Girguis, P.R. (2013) Characterizing microbial community and geochemical dynamics at hydrothermal vents using osmotically driven continuous fluid samplers. Environmental Science \& Technology, 47, 4399-4407.
Van Loon, L.R. and Glaus, M.A. (1997) Review of the kinetics of alkaline degradation of cellulose in view of its relevance for safety assessment of radioactive waste repositories. Journal of Environmental Polymer Degradation, 5, 97-109.

Van Loon, L.R., Glaus, M.A., Laube, A. and Stallone, S. (1999) Degradation of cellulosic materials under the alkaline conditions of a cementitious repository for low- and intermediate-level radioactive waste. II. Degradation kinetics. Journal of Environmental Polymer Degradation, 7, 41-51.

Vercammen, K., Glaus, M.A. and Van Loon, L.R. (1999) Complexation of calcium by alpha-isosaccharinic acid under alkaline conditions. Acta Chemica Scandinavica, 53, 241-246.

Zhilina, T.N. and Zavarzin, G.A. (1994) Alkaliphilic anaerobic community at $\mathrm{pH} 10$. Current Microbiology, 29, 109-112.

Zhilina, T.N., Kevbrin, V.V., Tourova, T.P., Lysenko, A. M., Kostrikina, N.A. and Zavarzin, G.A. (2005) Clostridium alkalicellum sp. nov., an obligately alkaliphilic cellulolytic bacterium from a soda lake in the Baikal region. Microbiology, 74, 557-566. 